\title{
GENETIC AND PHENOTYPIC TRENDS OF CALVING INTERVAL AND AGE AT FIRST CALVING IN A COMMERCIAL HOLSTEIN HERD
}

\author{
M.A.M. Ibrahim, H.E. Rushdi, S.A.M. Abdel-Salam and S. Abou-Bakr \\ Animal Production Department, Faculty of Agriculture, Cairo University, Giza, \\ Egypt
}

\section{SUMMARY}

Reproductive records of Holstein cows raised at a commercial farm during the period from 1991 to 2006 were used. A total of 3656 records of 1611 cow daughters of 413 sires and 588 dams were used to study genetic and phenotypic trends of age at first calving (AFC, mo) and calving interval $(C I, d)$. Two animal models were applied to estimate the genetic parameters and breeding values of the two traits using VCE program.

Genetic trend was estimated for the studied traits. Regression analyses by XLSTAT- Pro (2009) procedures were used to estimate genetic and phenotypic trends.

Means of CI and AFC were $484 d$ and 27.5 mo, respectively. Heritability estimates for CI and AFC were $0.07 \pm 0.01$ and $0.12 \pm 0.04$, respectively, while the corresponding estimate for repeatability of CI was 0.08 .

Genetic trends were $0.06 \mathrm{~d} / \mathrm{yr}$ and $0.02 \mathrm{mo} / \mathrm{yr}$ for CI and AFC, respectively. Phenotypic trends were -0.48 d /yr for CI -0.04 mo/yr for AFC.

Keywords: Reproductive traits, genetic trend, phenotypic trend, Holstein

\section{INTRODUCTION}

Animal improvement has been achieved by selection based on either phenotype or genetic merit of the superior animals for production traits. The practice of intensive selection programs for higher milk yields of dairy cattle has resulted in a significant reduction in reproductive efficiency caused by unfavorable genetic correlations between yield and fertility traits (Pryce et al., 2004; Ojango and Pollott, 2001; VanRaden et al., 2004; and Atil and Khattab, 2005).

Fertility traits may be economically more important than production traits (Berry and Cromie, 2009). Reproductive efficiency has a considerable impact on the overall profitability of dairy cattle production. Poor fertility increases costs due to fertility treatments and multiple inseminations, prolongs calving interval, and leads to a high replacement rate due to involuntary culling (Boichard, 1990; Dekkers, 1991; Gonzalez-Recio et al., 2004 and González-Recio and Alenda, 2005). To determine the effectiveness of breeding schemes, genetic trends in dairy cattle populations should be calculated. The estimation of genetic trend represents the best tool to follow genetic changes in a population (Falconer and Mackay, 1996 and Atil and Khattab, 2005).

Issued by The Egyptian Society of Animal Production 
Heritability estimates of reproductive traits in dairy cattle are generally low (often less than 5\%), making selection for those traits difficult (Lucy, 2001; Biffani et al., 2003; Amimo et al., 2006 and Abdelharith, 2008). Even though most reproductive traits have low heritabilities, monitoring reproductive performance has merit because after low milk yield, poor fertility is the leading reason for culling dairy cows (Berger et al., 1981).

The objective of this study was to estimate the genetic and phenotypic trends of $\mathrm{CI}$ and $\mathrm{AFC}$ of Holstein cows in a commercial farm.

\section{MATERIAL AND METHODS}

Reproductive records of Holstein cows raised at the International Company for Animal Wealth located at Giza Governorate during the period from 1991 to 2006 were used. The data included 3656 records of 1611 cow daughters of 413 sires and 588 dams. All cows were artificially inseminated by imported Holstein frozen semen from USA and Canada.

The traits selected for this study were age at first calving (AFC) and calving interval (CI) of Holstein cows.

\section{Statistical Analysis:}

Two statistical models were applied to estimate the genetic parameters and breeding value of reproductive traits using VCE 6.0.2 (Groeneveld et al., 2008) program. The repeatability animal model used for CI trait was as follow:

$$
\mathrm{Y}_{\mathrm{ijklmn}}=\mu+\mathrm{S}_{\mathrm{i}}+\mathrm{Y}_{\mathrm{j}}+\mathrm{PI}_{\mathrm{k}}+\mathrm{A}_{\mathrm{l}}+\mathrm{Per}_{\mathrm{m}}+\mathrm{e}_{\mathrm{ijklmn}}
$$

| $\mathrm{Y}_{\mathrm{ijklmn}}$ is the observed_CI,

$\mu \quad$ is the overall mean,

$\mathrm{S}_{\mathrm{i}} \quad$ is the fixed effect of $\mathrm{i}^{\text {th }}$ season of calving ( $\mathrm{i}=1,2,3$, and 4), where $1=1991$ $1994,2=1995-1998,3=1999-2002$ and $4=2003-2006$.

$Y_{j} \quad$ is the fixed effect of $j^{\text {th }}$ year of calving group $(j=1,2,3$, and 4$)$, where $1=$ winter (December - February), 2= spring (March, - May), 3= summer (June August) and $4=$ autumn (September - November).

$\mathrm{PI}_{\mathrm{k}} \quad$ is the fixed effect of $\mathrm{k}^{\text {th }}$ parity $(\mathrm{k}=1,2, \ldots$, and 6$)$,

$\mathrm{A}_{1} \quad$ is the random animal additive genetic effect,

$\mathrm{Per}_{\mathrm{m}} \quad$ is the random permanent environmental effect, and

$\mathrm{e}_{\mathrm{ijklmn}}$ is the random error assumed NID $\left(0, \sigma^{2} \mathrm{e}\right)$

The second model was used for AFC trait:

$\mathrm{Y}_{\mathrm{ijkl}}=\mu+\mathrm{S}_{\mathrm{i}}+\mathrm{Y}_{\mathrm{j}}+\mathrm{A}_{\mathrm{k}}+\mathrm{e}_{\mathrm{ijkl}}$

Where,

$\mathrm{Y}_{\mathrm{ijkl}}$ is the observation associated with the AFC trait,

$\mu \quad$ is the overall mean,

$\mathrm{S}_{\mathrm{i}} \quad$ is the fixed effect of $\mathrm{i}^{\text {th }}$ season of birth ( $\mathrm{i}=1,2,3$, and 4), where $1=$ Winter (December - February), 2= spring (March - May), 3= summer (June August) and autumn (September - November).

$\mathrm{Y}_{\mathrm{j}} \quad$ is the fixed effect of $\mathrm{j}^{\text {th }}$ year of birth group $(\mathrm{j}=1,2,3$, and 4$)$, where $1=1989$ $1992,2=1993-1996,3=1997-2000$ and $4=2001-2005$. 
$\mathrm{A}_{\mathrm{k}} \quad$ is the random animal additive genetic effect, and

$\mathrm{e}_{\mathrm{ijkl}} \quad$ is the random assumed $\operatorname{NID}\left(0, \sigma^{2} \mathrm{e}\right)$

The genetic trend was estimated as the linear regression coefficient of mean of breeding values on year of calving for CI and on year of birth for AFC, weighted by the number of animals in each year. Phenotypic trend was estimated by regressing phenotypic values on calving year for CI and on birth year for AFC. Genetic and phenotypic trends were estimated by XLSTAT (2009) procedures.

\section{RESULTS AND DISCUSSION}

Means and standard deviations for CI in days and AFC in months are shown in Table 1.

Table 1. Means and standard deviations (SD) for calving interval (CI) and age at first claving (AFC) of Holstein cows

\begin{tabular}{lccc}
\hline Trait & Records (No.) & Mean & SD \\
\hline CI, day & 3656 & 484 & 131 \\
AFC, month & 1611 & 27.5 & 2.7 \\
\hline
\end{tabular}

The present mean of CI was $484 \mathrm{~d}$, which was longer than the optimal CI performance of $365 \mathrm{~d}$. The average CI in the current study exceeded those obtained by Afifi et al. (2004), Salem et al. (2006) and Abdelharith (2008) on Friesian herds raised in Egypt. This result was comparable with means obtained from studies carried out in subtropical and tropical regions (Campos et al., 1994 and Amimo et al., 2006), but longer than those reported in temperate zones (González-Recio and Alenda, 2005 and Berry and Cromie, 2009) averaging 400 and 390 days, respectively. Ojango and Pollott (2001) indicated that the negative energy balance during early lactation in high-producing cows could affect the onset of estrus and hence result in longer calving intervals. Calving interval has a high economic weight as reduction in CI could improve the overall productivity of the herd.

Age at first calving in the present study averaged $27.5 \mathrm{mo}$, which was in close agreement with that reported by Abdelharith (2008). Afifi et al. (2004) found a younger average AFC (23.7 mo), while Salem et al. (2006) reported an older AFC (29.2 mo) compared to our study. Age at first calving in this study is lower than mean estimates of AFC in Italy (28.2 mo; Pirlo et al., 2000), in Spain (28.6 mo; Perez et al., 1999), and in Kenya (31 mo; Ojango and Pollott, 2001) for Holstein dairy herds. It has been reported that AFC of 22 months followed by a reduced CI has resulted in an increment in the productive life of dairy cows, which consequently has an influence on shortening the generation interval and accelerating the annual rate of genetic change through selection (Amimo et al., 2006). Older cows at first calving had increased risk of being culled earlier post-first calving (Berry and Cromie, 2009). The same authors reported that the optimal AFC depends on the prevailing economic situation such as milk price, cull cow price, cost of feed and other inputs (e.g. labor, housing).

Table (2) illustrates heritability and repeatability estimates for the two studied traits. In general, low estimates of genetic parameters for reproductive traits were obtained in other studies (Campos et al., 1994; Dematawewa and Berger, 1998; Ojango and Pollott, 2001; Amimo et al., 2006; and Pozveh et al., 2009). 
Table 2. Estimates of heritability $\left(h^{2} \pm \mathrm{SE}\right)$, and repeatability $(r)$ for calving interval (CI) and age at first calving (AFC) of Holstein cows.

\begin{tabular}{llc}
\hline Trait & $h^{2} \pm \mathrm{SE}$ & $\mathrm{r}$ \\
\hline CI & $0.07 \pm 0.01$ & 0.08 \\
$\mathrm{AFC}$ & $0.12 \pm 0.04$ & - \\
\hline
\end{tabular}

Heritability estimate for CI was $0.07 \pm 0.01$ (Table 2), which was similar to that obtained by Pozveh et al. $(0.07,2009)$. This estimate was somewhat greater than 0.04 published by Wall et al. (2003) and González-Recio and Alenda (2005) and Amimo et al. (2006), and less than 0.09 reported by Campos et al. (1994) and Atil and Khattab (2005). Our estimate of heritability was greater than has previously been reported for different Holstein-Friesians herds in Egypt (Afifi et al., 2004; and Abdelharith, 2008). In addition, Atil and Khattab (2005) suggested that a large proportion of the phenotypic variation in CI was mainly caused by differences in temporary environmental components and herds management systems.

Table 2 shows that the repeatability estimate for CI was 0.08 . This estimate was close to that obtained by Abdelharith $(0.07,2008)$ and less than that obtained by Silva et al. $(0.1,1992)$. It can be concluded that the low estimate of repeatability in this study is an indication that $\mathrm{CI}$ is more affected by temporary environmental factors, rather than genetic and permanent environmental ones. Therefore, it would be thus possible to shorten the length of CI by improving reproductive management strategies within dairy herds.

The estimate of heritability for AFC was 0.12 , which was in agreement with that obtained by Abdelharith $(0.13,2008)$. Age at first calving is known to be as a trait with small genetic variation. However, in the current study it is more heritable trait compared to calving interval (Table 2).

Genetic improvement of reproductive traits is slow and does not reduce the need for appropriate management techniques. Genetic improvement could reduce breeding costs because of isolation, treatment, culling and replacement of problem cows. Adequate methods of selecting dairy cattle and of improving herd reproductive efficiency depend on how genetic progress for milk yield influences reproductive performance. The cow's genetic merit for milk can affect reproductive performance, perhaps by increasing stress (Campos et al., 1994).

\section{Genetic and phenotypic trends of the studied traits:}

The phenotypic trend of CI, as shown in Figure 1, was non-significantly negative (- $0.48 \pm 0.96 \mathrm{~d} / \mathrm{yr}, \mathrm{P}>0.05)$. The corresponding genetic trend for CI was significantly positive $0.06 \pm 0.02 \mathrm{~d} / \mathrm{yr}, \mathrm{P}<0.015$, indicating a genetic increase in calving interval over time (Figure 2). Our result was comparable with that obtained by Abdelharith (2008), who reported estimates of genetic and phenotypic trends $0.03 \pm 0.03 \mathrm{~d}$ per year and $-0.09 \pm 0.17 \mathrm{~d}$ per year, respectively, for CI. In addition, Atil and Khattab (2005) estimated the genetic trends for CI and $305 \mathrm{~d}$ milk yield to be $-0.95 \mathrm{~d} /$ year and $44.85 \mathrm{~kg} / \mathrm{yr}$. They concluded that selection objective focused on choosing the best sires and cows to be the next generation parents would lead to increase in milk traits and decrease in reproductive traits simultaneously. Numerous publications confirmed that selection for milk production with little or no emphasis on reproduction has led 
to a decline in reproduction performance in dairy populations (Ojango and Pollot 2001; Weller and Ezra, 2004; González-Recio and Alenda, 2005; and Berry and Cromie, 2009).

The genetic trend in AFC was positive (Fig. 3), indicating a genetic increase in AFC over time. The regression of breeding value for AFC on year of birth was significant positive $(0.02 \pm 0.003 \mathrm{mo} / \mathrm{yr}, \mathrm{P}=0.000)$. The results obtained in the current study correspond to previous results for the Israeli Holstein population (Weller and Ezra, 2004) and for Simmental breed in Slovenia (Potoenik et al. 2000), but disagree with other studies that have mentioned negative genetic trend for AFC (Amimo et al., 2006; Abdelharith, 2008). In contrast, phenotypic trend (Fig. 4) in AFC was nonsignificantly negative $(-0.04 \pm 0.06 \mathrm{mo} . / \mathrm{yr}, \mathrm{P}>0.05)$. This decrease is due to better management of calves and heifers and realization of the economic importance of earlier first calving.

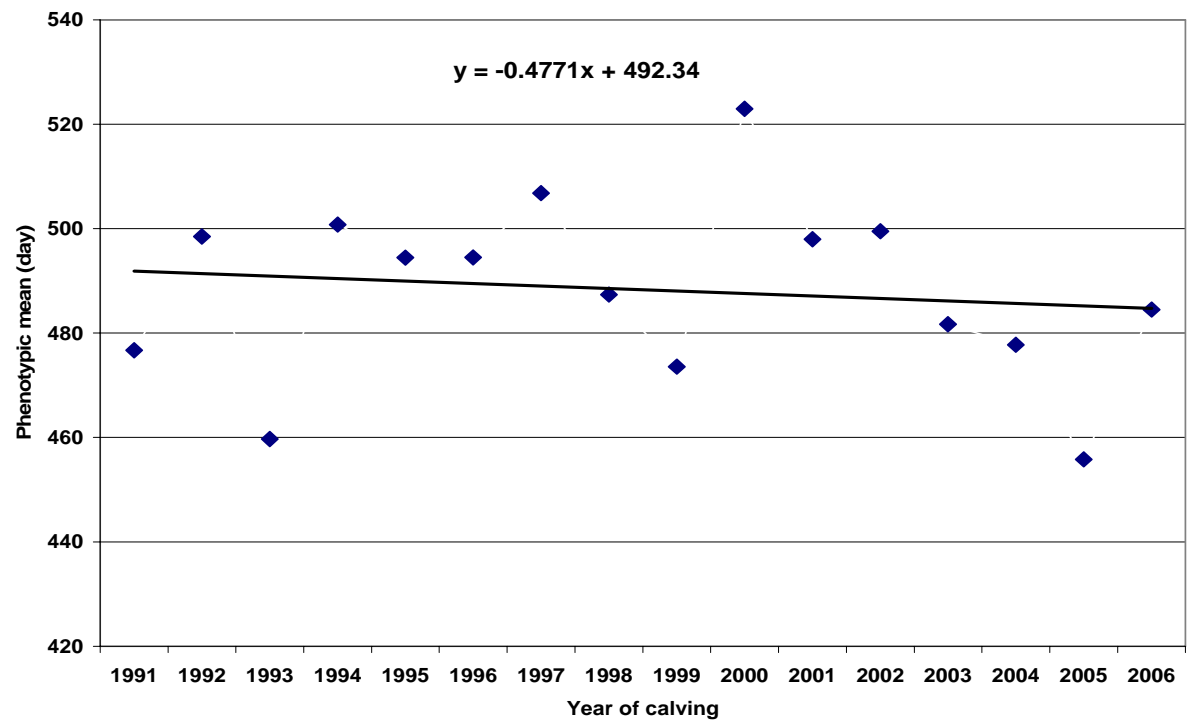

Figure 1. Phenotypic trend of CI of Holstein cows 


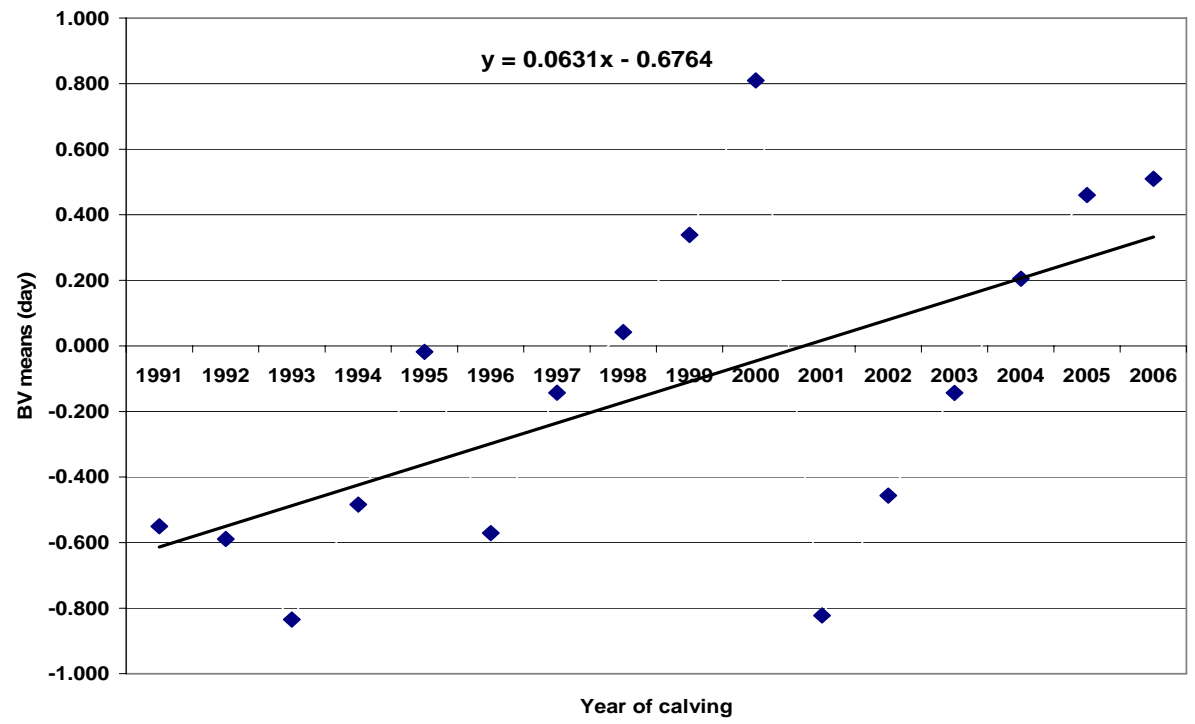

Figure 2. Genetic trend for CI of Holstein cows

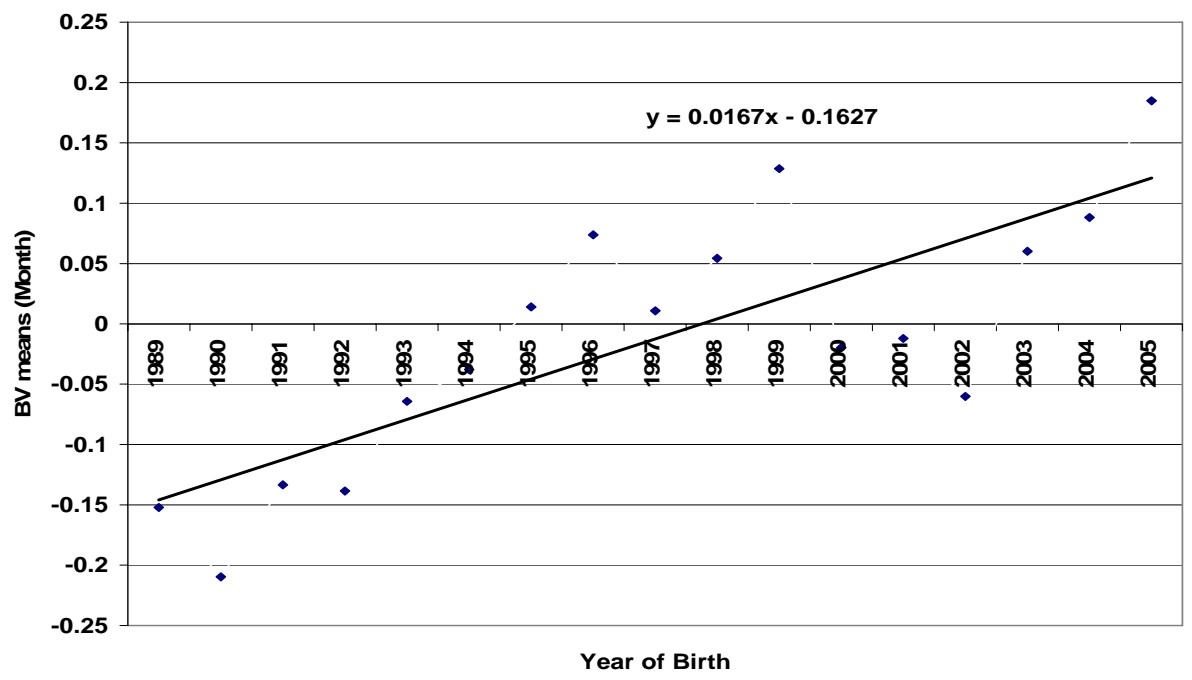

Figure 3. Genetic trend for AFC of Holstein cows 


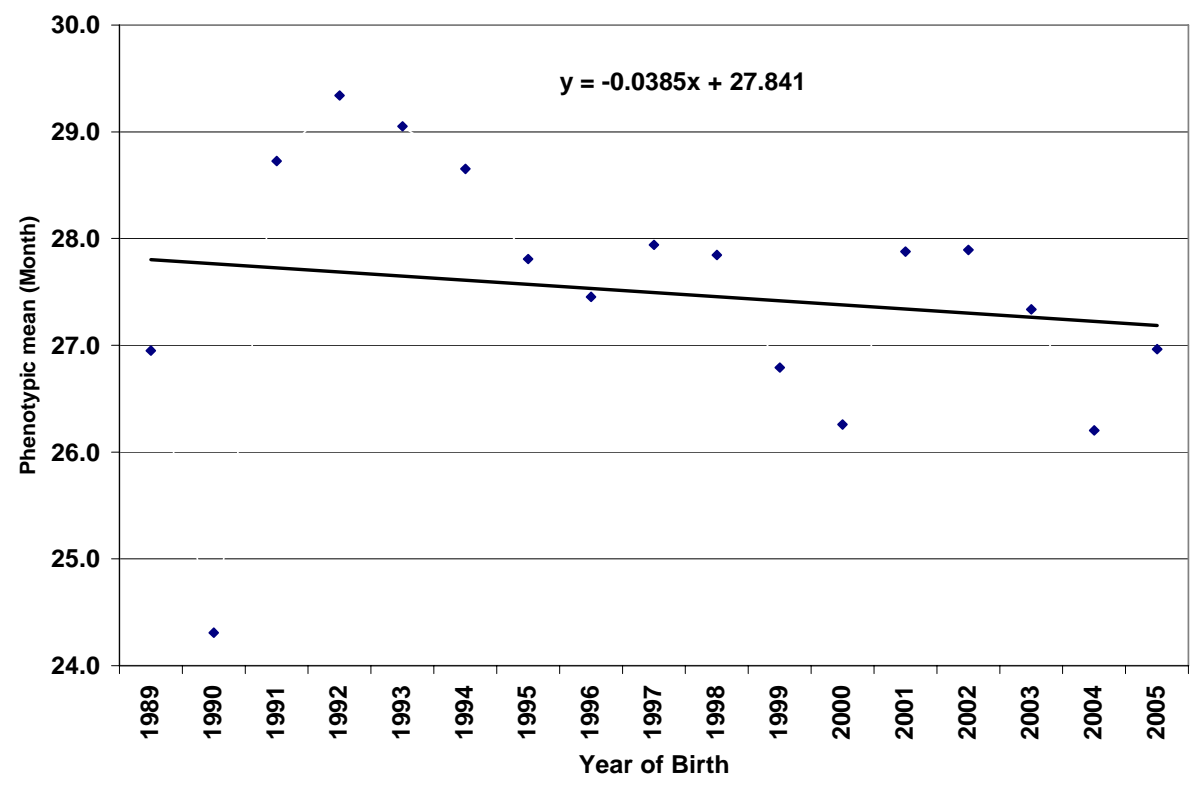

Figure 4. Phenotypic trend for AFC of Holstein cows

\section{CONCLUSIONS}

Heritability and repeatability estimates for CI and AFC were in the range of those previously reported in the literature. Low estimates of reproductive traits in this study support the idea that genetic selection to improve reproductive traits is probably unwarranted.

\section{REFERENCES}

Abdelharith, Hanaa, 2008. Genetic and phenotypic trends of milk yield and reproductive traits for Friesian herd raised in Mid-Delta. Egypt. J. Appl. Sci., 23(8A):1-14.

Afifi, E.A., M.A. Salem, S.A. Arafa and M.E. Gad, 2004. Some correction factors for milk yield and repeatability estimates for productive and reproductive traits of Friesian cattle in three commercial herds raised in Egypt. Annals of Agric. Sc., Moshtohor. 42 (2): 541-553.

Amimo, J.O., R.O. Mosi, J.W. Wakhungu, T.K. Muasya and B.O. Inyangala, 2006. Phenotypic and genetic parameters of reproductive traits for Ayrshire cattle on large-scale farms in Kenya. Livestock Research for Rural Development. 18(10): 20-32

Atil, H. and A.S. Khattab, 2005. Estimation of genetic trends for productive and reproductive traits of Holstein-Friesian cows in Turkey. Pakistan J. Biol. Sci. 8 (2): 202-205. 
Berger, P.J., R.D. Shanks, A.E. Freeman and R.C. Laben. 1981. Genetic aspects of milk yield and reproductive performance. J. Dairy Sci., 64: 114.

Berry, D.P. and A.R. Cromie, 2009. Associations between age at first calving and subsequent performance in Irish spring calving Holstein-Friesian dairy cows. Livestock Science. 123: 44-54.

Biffani, S., A.B. Samore, F. Canavesi and M. Marusi, 2003. Data quality assessment and preliminary investigations on fertility in the Italian Holstein Friesian. Interbull Bulletin No. 30.Proceedings of the Interbull Technical Workshop. Beltsville. MD, USA. March 2-3, 2003.Pp89-95.

Boichard, D., 1990. Estimation of the economic value of conception rate in dairy cattle. Livest. Prod. Sci., 24: 187-204.

Campos M.S, C.J. Wilcox, C.M. Becerril and A. Diaz, 1994. Genetic parameters for yield and reproductive parameters of Holstein and Jersey cattle in Florida. J. Dairy Sci. 77: 867-873.

Dekkers, J.C.M., 1991. Estimation of economic values for dairy cattle breeding goals: bias due to sub-optimal management policies. Livest. Prod. Sci.,29: 131149.

Dematawewa, C.M.B. and P.J. Berger, 1998. Genetic and phenotypic parameters for 305-day yield, fertility, and survival in Holsteins. J. Dairy Sci. 81: 2700-2709.

Falconer, D.S. and T.F.C. Mackay, 1996. Introduction to quantitative genetics. $4^{\text {th }}$ ed. Longman, Essex - England, 464 p.

González-Recio, O., M.A. Perez-Cabal and R. Alenda, 2004. Economic value of female fertility and its relationship with profit in Spanish dairy cattle. J. Dairy Sci., 87: 3053-3061.

González-Recio, O. and R. Alenda, 2005. Genetic Parameters for Female Fertility Traits and a Fertility Index in Spanish Dairy Cattle. J. Dairy Sci. 88: 3282-3289.

Groeneveld, E.; M. Kovac and N. Mielenz, 2008. VCE 6.0.2, Co-variance components estimation package, Institute of Farm Animal Genetics, Mariensee, Germany.

Lucy, M.C., 2001.Reproductive loss in high-producing dairy cattle: Where will it end? J.Dairy Sci., 84:1277-1293.

Ojango, J.M. and G.E. Pollott, 2001. Genetics of milk yield and fertility traits in Holstein-Friesian cattle on large-scale Kenyan farms. J. Anim. Sci. 79: 17421750.

Perez, M.A., D. Hernandez, R. Alenda, M.J. Carabano and N. Charfeddine, 1999. Genetic analysis of true profit for Spanish dairy cattle. www.interbull.slu.se/bulletins/bulletin23/perez.pdf.

Pirlo, G., F. Miglior and M. Speroni, 2000. Effect of age at first calving on production traits and on difference between milk yield returns and rearing cost in Italian Holsteins. J. Dairy Sci. 83: 603-608.

Potoenik, K., M. Stepec and J. Krsnik, 2000. Genetic trends for production and nonproduction traits in Simmental breed in Slovenia. www.bfro.uni-ljsi/2000/org/centre/objave.

Pozveh, S.T., A.A. Shadparvar, M.M. Shahrbabak and M.D. Taromsari, 2009. Genetic analysis of reproduction traits and their relationship with conformation traits in Holstein cows. Livestock Science (in press). 
Pryce, J. E., M. D. Royal, P. C. Gransworthy, and I. L. Mao. 2004. Fertility in highproducing dairy cow. Livestock Prod. Sci. 86: 125-135.

Salem, M.A., H.M. Ismail, R.R. Sadek and A.A. Nigm, 2006. Phenotypic and genetic parameters of milk production and reproductive performance of Holstein cattle under the intensive production system in Egypt. Egypt. J. Anim. Prod. 43 (1):110.

Silva, H.M., C.J. Wilcox, W.W. Thatcher, R.B. Becker and D. Morse, 1992. Factors affecting days open, gestation length and calving interval in Florida dairy cattle. J. Dairy Sci., 75: 288-293.

VanRaden, P.M., A.H. Sanders, M.E. Tooker, R.H. Miller, H.D. Norman, M.T. Kuhn and G.R. Wiggans, 2004. Development of a National Genetic Evaluation for Cow Fertility. J. Dairy Sci. 87: 2285-2292.

Wall, E., S.Brotherstone, J.A. Woolliams, G. Banas and M.P. Caffey, 2003. Genetic evaluation of fertility using direct and correlated traits. J.Dairy Sci., 86: 40934102.

Weller, J.I. and E. Ezra, 2004. Genetic Analysis of the Israeli Holstein Dairy Cattle Population for Production and Nonproduction Traits with a Multitrait Animal Model. J. Dairy Sci. 87: 1519-1527,

XLSTAT,2009. Statistical software for MS Excel- Statistics and data analysis with MS. 
الإتجاهات الوراثية و المظهرية لصفة الفترة بين ولادتيين و العمر عند أول ولادة لابقار الهولستين فى قطيع تجارى الأنه

\section{محمد عبد العزيز محمد ابراهيم، حسام الدين رشدى،سامح عبد السلام و سامى أبوبكر قسم الإنتاج الحيوانى، كلية النزراعة، جامعة القاهرة، الجبزة ، جمهورية مصر العربية}

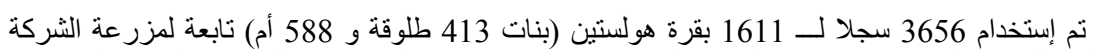

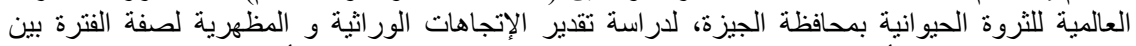

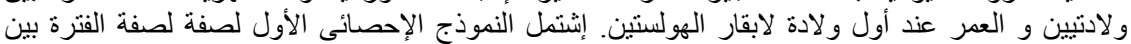

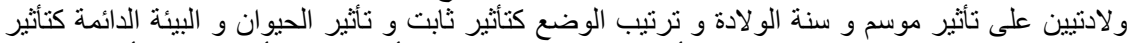

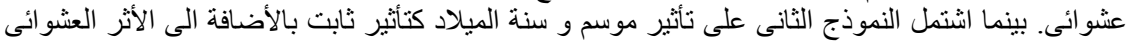

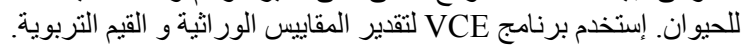

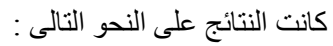

1- منوسط كلا من صفة الفترة بين و لادتيين و العمر عند أول و لادة هو 484 يوم و 27.5 شهر، على

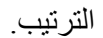

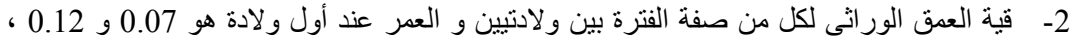

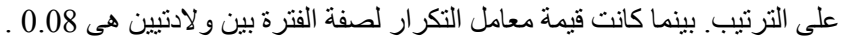

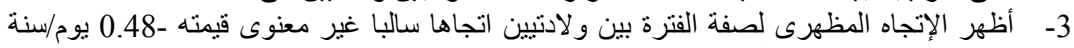

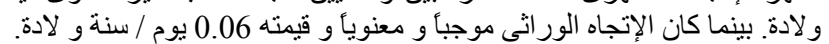

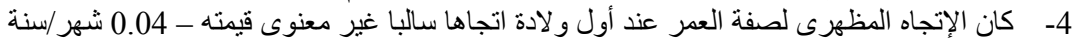
ميلاد. بينما كان الإتجاه الور اثتى موجبا معنويا (0.02 شهر اسنة ميلاد). 